\title{
Astrocytomas: Old and Newly Recognized Variants, Their Spectrum of Morphology and Antigen Expression
}

\author{
John J. Kepes
}

\begin{abstract}
The relationship between the morphology of astrocytomas and their prognosis is complex, with the localization of the tumour, the predominant cell type and the degree of anaplasia all playing an important part in determining the patient's future. Since many astrocytomas have a diversity of patterns, small needle biopsies taken from just one or a few areas may fail to elucidate the principal features of a given tumour. In addition to the astrocytoma subtypes listed in the WHO's International Histological Classification of brain tumours, new entities have been observed in the last few years. These include lipidized forms, such as the relatively benign pleomorphic xanthoastrocytoma and the highly malignant lipidized glioblastoma. Neoplastic astrocytes are capable of forming basal laminae and of phagocytosis, and often contain alpha-1-antitrypsin, features that may lead to confusing them with histiocytes. They may be arranged in a whorled pattern imitating meningiomas, their my xoid intercellular stroma may assume the morphology of cartilage and closely packed tumour cells in "epitheloid" astrocytomas come close to imitate metastatic carcinoma. Some astrocytomas contain cells indistinguishable from those of granular cell tumours of other tissues. The presence of reactive lymphocytes in astrocytomas and reactive astrocytes in malignant lymphomas can be the source of confusion between those two kinds of neoplasms.
\end{abstract}

\begin{abstract}
RÉSUMÉ: Astrocytomes: formes déjà reconnues et formes nouvellement identifiées. Eventail de leur morphologie et de leur expression antigénique La relation entre la morphologie des astrocytomes et leur pronostic est complexe, la localisation de la tumeur, le type cellulaire prédominant et le degré d'anaplasie jouant un rôle important dans la détermination du sort du patient. Plusieurs astrocytomes ayant une morphologie diversifiée, les biopsies à l'aiguille fine faites seulement dans une ou dans quelques régions de la tumeur pevent ne pas mettre en évidence les principales caratéristiques de la tumeur. En plus des sous-types d'astrocytomes catalogués dans la Classification Histologique Internationale de l'OMS des tumeurs du cerveau, de nouvelles entités ont été signalées au cours des dernières années. Parmi ces entités, notons les formes à contenu lipidique, tel le xanthoastrocytome pléomorphe qui est relativement bénin et le glioblastome à contenu lipidique qui est très malin. Les astrocytes néoplasiques sont capables de phagocytose et de former des membranes basilaires et ils contiennent souvent de l'alpha-1-antitrypsine. Ces caractéristiques peuvent amener l'observateur à les confondre avec des histiocytes. Ils peuvent être disposés en tourbillons, imitant la disposition cellulaire des méningiomes; leur stroma intercellulaire myxoïde peut simuler la morphologie du cartilage et les cellules tumorales en groupes serrés des astrocytomes épithélioïdes imitent de près le carcinome métastatique. Certains astrocytomes contiennent des cellules impossibles à distinguer de celles des tumeurs à cellules granuleuses provenant d'autres tissus. La présence de lymphocytes réactionnels dans les astrocytomes et d'astrocytes réactionnels dans les lymphomes malins peut être une source de confusion entre ces deux variétés de néoplasmes.

Can. J. Neurol. Sci. 1987; 14:109-121
\end{abstract}

It is indeed a great honor for me to have been invited to deliver this year's Jerzy Olszewski lecture of the Canadian Association of Neuropathologists. What makes this invitation even more special for me is the fact that I am not even a Canadian and it has not been my lot to have had the pleasure and honor to know Dr. Olszewski personally. As a neuropathologist naturally I had ample opportunity to read and study Dr. Olszewski's contributions to our discipline, many of which can quite safely be considered to be of historic importance. There are however also some common traits in our personal backgrounds. Both of us came from the Eastern part of Central Europe, he from Poland, myself from Hungary, and both of us have lived through some stormy times there, but eventually we both found the golden opportunity to serve and practice the science of medicine in the Western Hemisphere: Dr. Olszewski in your lovely land Canada and myself in the United States,

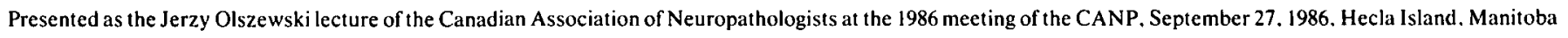
From the Department of Pathology and Oncology, The University of Kansas, College of Health Sciences and Hospital, Kansas City, Kansas. U.S.A. 
both of them countries that in neurological parlance proved to be "final common pathways" for many European professionals.

For a significant part of his career Dr. Olszewski's primary interest was the normal anatomy and histology of the human brain, a line of investigation for which he was uniquely well prepared, having worked as an associate to Cecile and Oscar Vogt for several years in Germany. His magnificent tome: the Cytoarchitecture of the Human Brain Stem' written with Dr. Baxter is a cherished possession of our own neuropathology laboratory in Kansas City, and of many other contemporary centers. After contributing numerous scholarly works on the normal structure of the brain, Dr. Olszewski turned his investigative acumen and talents of observation to pathologic changes of the nervous system. His papers in this field covered the past, the recent developments and even served as a basis for the future. For example, his scholarly work on Binswanger's disease $^{2}$ provided new understanding and views of a disease known since the end of the 19th century. When central pontine myelinolysis had just been discovered, within a year of the first report, Dr. Olszewski, together with Dr. Berry, already contributed an important observation on this entity, ${ }^{3}$ and I don't need to remind you that in the historic paper on progressive supranuclear palsy, ${ }^{4}$ a disease that together with Drs. Steele's and Richardson's bears his name, Dr. Olszewski introduced to us a disease that was heretofore unknown and very little, indeed, could be added to the descriptive microscopic findings of this entity, to what Dr. Olszewski has already taught us. Also, we may note that Binswanger's disease represents an example of cerebrovascular problems, central pontine myelinolysis, one of metabolic derangements of the white matter, and progressive supranuclear palsy is a degenerative disease of neurons. This indicates that Dr. Olszewski certainly moved with practiced ease in the various territories within his favorite discipline. In the area of neoplasms Dr. Olszewski, together with his colleague Dr. Rothballer, provided a most selfless service by translating Zülch's textbook on brain tumours from German to English. ${ }^{5}$ Undoubtedly his perfect knowledge of the German language enabled him to take part in a most faithful translation of this important book that acquainted American readers with Dr. Zülch's work. In doing so, Dr. Olszewski successfully contributed to the closing of some of the gaps in the understanding of brain tumours that existed at the time between the two sides of the Atlantic Ocean.

It is from this particular section of Dr. Olszewski's endeavors, the area of brain tumours, that I have chosen the subject for this presentation which deals with present trends in our understanding of the morphology of astrocytic neoplasms. As you know, a fairly recent major step aimed at providing a common denominator to the terminology of brain tumours was the effort of the World Health Organization (WHO) to establish a universally acceptable system of histologic typing of human brain tumours. ${ }^{6}$ The Commission in charge of this work was chaired by the same K.J. Zülch whose textbook Dr. Olszewski had so ably translated for us back in 1957. Although the work by the WHO is relatively recent and up-to-date, the recommended classification (depicted in Table 1) does not include all of the presently known histologic variants of astrocytomas, and at the same time does not adequately stress the combination of factors that usually determines the prognosis of astrocytomas. The diagram of Figure 1 illustrates the interwoven and overlapping nature of diverse features and characteristics of astrocytomas that have
Table 1: Tumours of the astrocytic series as tabulated in the WHO histological classification of tumours of the central nervous system.

A. ASTROCYTIC TUMOURS

1. Astrocytoma

a. fibrillary

b. protoplasmic

c. gemistocytic

2. Pilocytic astrocytoma

3. Subependymal giant cell astrocytoma (ventricular tumour of tuberous sclerosis)

4. Astroblastoma

5. Anaplastic (malignant) astrocytoma

F. POORLY DIFFERENTIATED AND EMBRYONAL TUMOURS

I. Glioblastoma

Variants:

a. Glioblastoma with sarcomatous component (mixed glioblastoma and sarcoma)

b. Giant cell glioblastoma

*Modified from Zülch KJ: Histological Typing of Tumours of the Central Nervous System, Section A, p. 19 and Section F, p. 20. Reproduced with permission of World Health Organization, Geneva, Switzerland.

to be considered together before prognosis in a given patient can be projected. Thus, the localization of the tumour is one aspect of utmost importance because, for example, even low grade astrocytomas involving the brain stem have a very guarded prognosis whereas cerebral hemispheric astrocytomas by virtue of their localization fare somewhat better and of course, many cerebellar astrocytomas, particularly if they are cystic and have a mural nodule that can be removed at the time of surgery, offer a good promise for cure. The second consideration has to be the cell type i.e. attention must be given to the nature of the majority of neoplastic astrocytes in a tumour: whether they are of the fibrillary, gemistocytic, lipidized, etc. category, and thirdly after taking into account the above morphological subtypes, within each of them the degree of anaplasia (individual cell differentiation, the number of mitotic figures, the presence or absence of necrosis, etc.) has to be reviewed. No valid prognosis can be contemplated for a patient who suffers from an astrocytoma, unless all of the above three aspects of his or her tumour are being taken into consideration.

The explanatory notes of the WHO classification emphasize that it is based largely on the predominant cell types, since it is recognized that for example "many astrocytomas are composed of different types of astrocytes." This latter problem is becoming of ever increasing importance in this day and age when biopsies are taken using stereotactically directed needles, which as a rule provide only small pieces of tissue for analysis. The location of the biopsy can be of utmost importance, because problems of sampling in the case of primary brain tumours may lead to serious diagnostic difficulties. One such problem is that the same astrocytoma that may be of low cellularity without anaplasia or mitotic figures in one area (Figure 2) could have foci a few $\mathrm{cms}$ away from the first mentioned area, that have a high degree of cellularity with cells that exhibit immaturity, anaplasia and bizarre pleomorphism (Figure 3). The diagnosis of Figure 1 would be a low grade fibrillary astrocytoma, whereas the territory shown in Figure 2 certainly would warrant at least the term anaplastic astrocytoma.

As to morphologic variants, in addition to the varieties listed in the WHO classification, I would like to briefly outline some of the additional histologic features that one might observe in astrocytomas. Some of these may sufficiently alter the micro- 
scopic appearance of the tumour to make it difficult to even identify it as being an astrocytoma as opposed to some other type of neoplasm, with far reaching differences in prognosis. For this reason I believe that in any discussion of the morphologic spectrum of astrocytomas these variants should be included. Examples of histologic variants include the ones with changes brought about by 1) lipidization of tumour cells, in particular as they may create a close similarity to lipidized mesenchymal neoplasms (e.g. variants of fibrous histiocytomas), 2) a whorling pattern of neoplastic astrocytes, imitating the appearance of meningiomas, 3) myxoid and chondroid changes, 4) the occasional clustering of neoplastic astrocytes producing compact cell nests that closely imitate epithelial tumours, and finally 5) the granular alterations of the cytoplasm of neoplastic astrocytes which bring about a cerebral form of granular cell tumours that happen to be of astrocytic origin.

In addition I shall want to comment on some of the diagnostic difficulties caused by the presence of lymphocytic infiltrates in astrocytomas, and conversely, by marked reactive astrocytic gliosis that may occur in cerebral lymphomas, both of which at times may make the distinction between astrocytic and lymphoreticular neoplasms quite difficult.

\section{Lipidization of Astrocytomas}

When dealing with the presence of lipidized cells within gliomas one must first of all realize that not all such cells are necessarily a part of the tumour parenchyma. Macrophages, some of them heavily lipidized, may infiltrate gliomas, particularly if there is necrosis in such tumours, but even in areas far removed from recognizable necrosis such lipid containing macrophages may occur individually or form cell clusters. In general, they may be distinguished from truly neoplastic cells by virtue of their benign appearing small dark nuclei. Such cells are illustrated in Figure 4. In an entirely different category one may encounter astrocytomas where the tumour cells themselves contain lipid. Changes of this type may be found both in relatively benign gliomas as well as in highly malignant glioblastomas. In 1978 at the VIIIth International Congress of Neuropathology in Washington, D.C., ten cases of young individuals with ages ranging from 7 to 16 years at the onset of their symptoms, and who had superficially located, often cystic hemispheric tumours with many lipidized astrocytes (Figure 5) were presented. ${ }^{7}$ This was followed by a more detailed report of this entity that was named pleomorphic xanthoastrocytoma. ${ }^{8}$ Some of these same neoplasms had been earlier considered to represent lipidized fibrous histiocytomas of the meninges or the brain ${ }^{9}$ but the advent of stains for glial fibrillary acidic protein (GFAP) made it possible to identify the cells so involved as being neoplastic astrocytes (Figure 6). It was not only the lipid content of the tumour cells (Figure 7) that suggested at one time that one might be dealing with fibrous xanthomas in these cases, but also the presence of occasionally numerous chronic inflammatory cells, as well as the finding of reticulin fibers (basal laminae by electron microscopy) surrounding individual tumour cells (Figure 8), a feature heretofore usually associated only with tumours of mesenchymal derivation. Neoplastic astrocytes in

\footnotetext{
*The patient reported by Weldon-Linne et al ${ }^{13}$ developed malignant transformation of his tumour and died within two years after surgery, but had a long ( 16 years) preoperative course with symptoms referrable to the presence of the tumour.
}

the past have not been credited with the ability to form basal laminae, although Helen Ramsey in 1965 had already demonstrated in her study on the fine structure of the surface of the normal human cerebral cortex, that the most superficial i.e. subpial astrocytes are invested by basal laminae. ${ }^{10}$ It is perhaps not just a coincidence that most of the pleomorphic xanthoastrocytomas occur close to the surface in the cerebral hemispheres and some of them actually involve the meninges. The observation of astrocytes forming basal laminae is not restricted to human material: for example Kusaka et al in 1985 have shown that astrocytes in organotypic cultures of mouse spinal cord tissue are also engaged in basal lamina formation. " Pleomorphic xanthoastrocytomas have a certain importance as a subcategory of gliomas, because they preferentially involve young subjects and appear to have a relatively favorable prognosis. Of the original 12 patients that Dr. Rubinstein, Eng and myself reported in Cancer, 1979, one had already died at the time of the report after a prolonged disease that covered several decades, three have died since the publication of the article, one patient was lost to follow-up, but the remaining seven patients, according to latest follow-up notes, are still alive and tumour free more than seven years after the publication of the cases. (A number of them even at that time were already several years after their surgery.) This relatively favorable prognosis has been borne out by experiences in this ${ }^{12.13 *}$ and other countries as manifested in the review of pleomorphic xanthoastrocytomas in Scandinavia, ${ }^{14}$ and in cases reported from Canada, ${ }^{15}$ Japan, ${ }^{16}$ Argentina, ${ }^{17}$ Colombia, ${ }^{18}$ Great Britain ${ }^{19}$ and Italy, ${ }^{20}$ with one recently reported case from the latter country being particularly encouraging, this one by Dr. Palma et al from Rome, who, in 1985 , reported 18 year symptom free survival in a patient with pleomorphic xanthoastrocytoma. ${ }^{21}$

While the cells of pleomorphic xanthoastrocytomas show cytoplasmic and nuclear variation and some mitotic figures may be present in such tumours, it appears that the presence of necrosis is a histologic phenomenon that would exclude a given tumour from this category. If and when areas of coagulation necrosis are found in a lipidized astrocytoma, we are usually dealing with a glioblastoma with lipidized cells. This category contains cases that have markedly different characteristics from pleomorphic xanthoastrocytomas: they are liable to occur in middle aged and older people and they are not necessarily

Figure I - Diagram to illustrate the factors determining prognosis in an astrocytic neoplasm.

Figure 2 - Portion of a frontal lobe astrocytoma in a young adult: well differentiated fibrillary astrocytes. (H\&E $\times 160)$

Figure 3 - Same tumour as in Fig . 2. different area: here the tumour is much more cellular and shows increased cellularity and anaplasia. (H\&E.x 160)

Figure 4 - Anaplasticastrocytoma withclusters of benignfoamymacrophages, distinguished by their small and regular nuclei in contrast to pleomorphic tumour cells. (H\&Ex /80)

Figure 5 - Pleomorphic xanthoastrocytoma. The cells show great variation in morphology and many contain fat droplets in their cytoplasm. Necrosis is absent. $(H \& E \times 320)$

Figure 6 - Same case as in Fig. 5. The peripheral portion of alipid-laden cell in the center, and cell processes contain glial fibrillary acidic prolein. (Immunoperoxidase stain for GFAP x 360) 

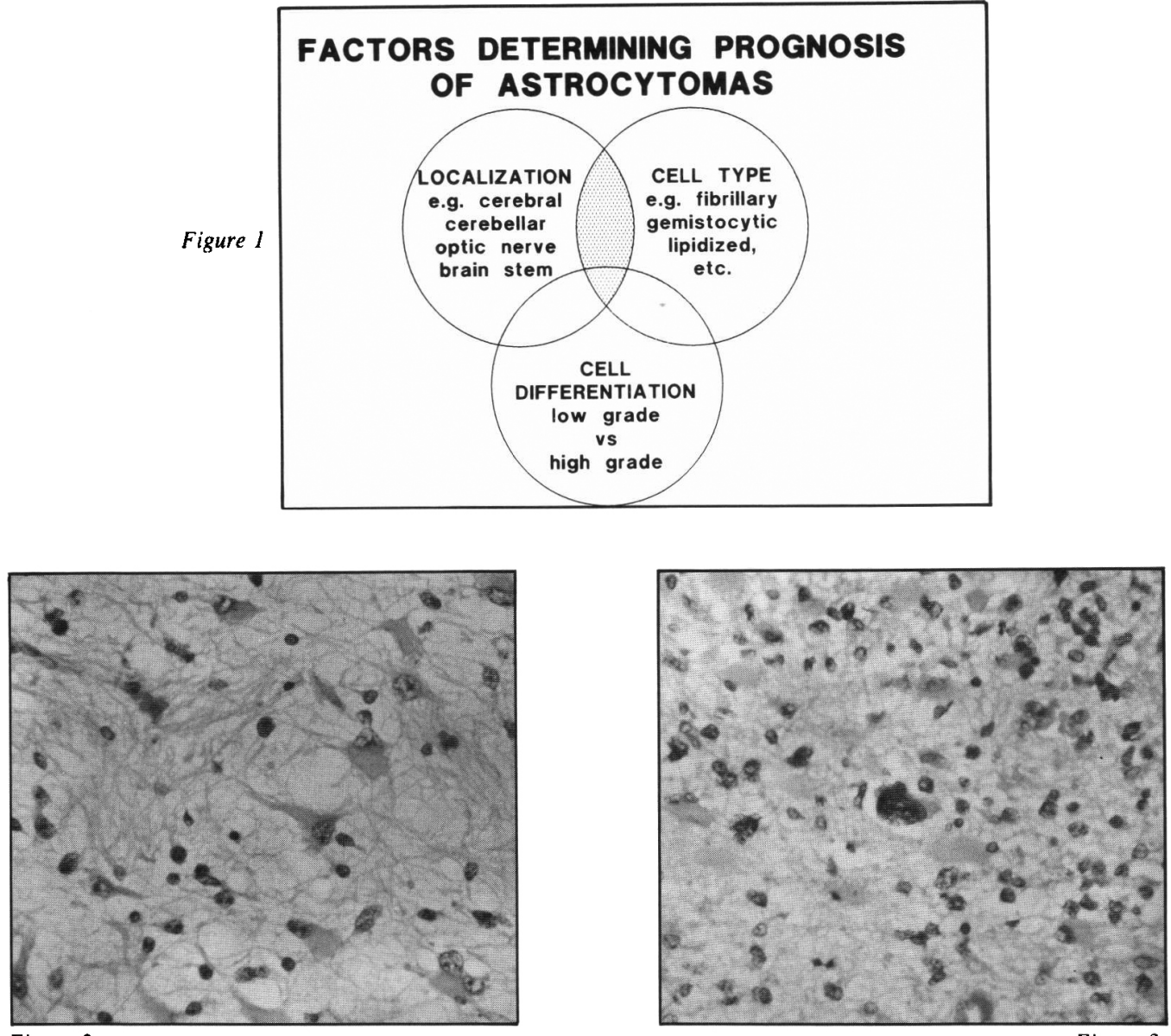

Figure 2

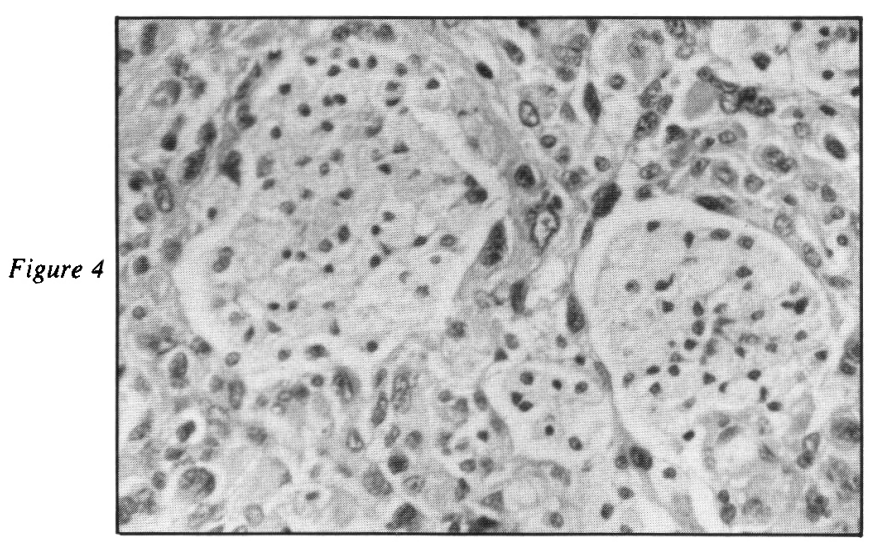

Figure 3
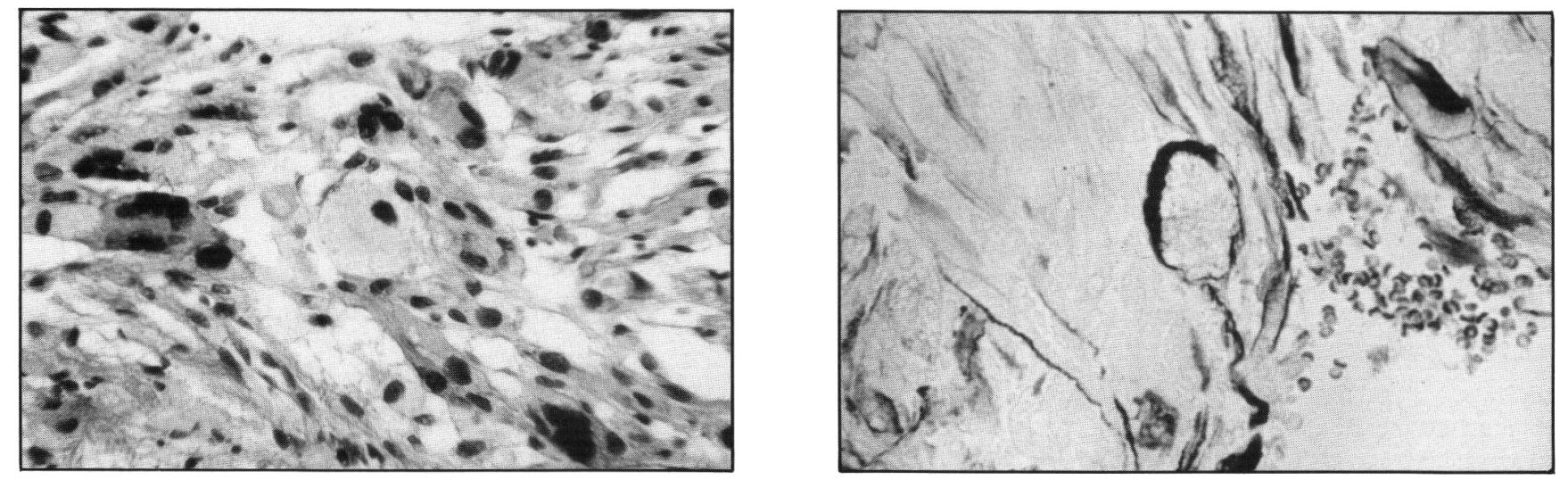

Figure 5

Figure 6 


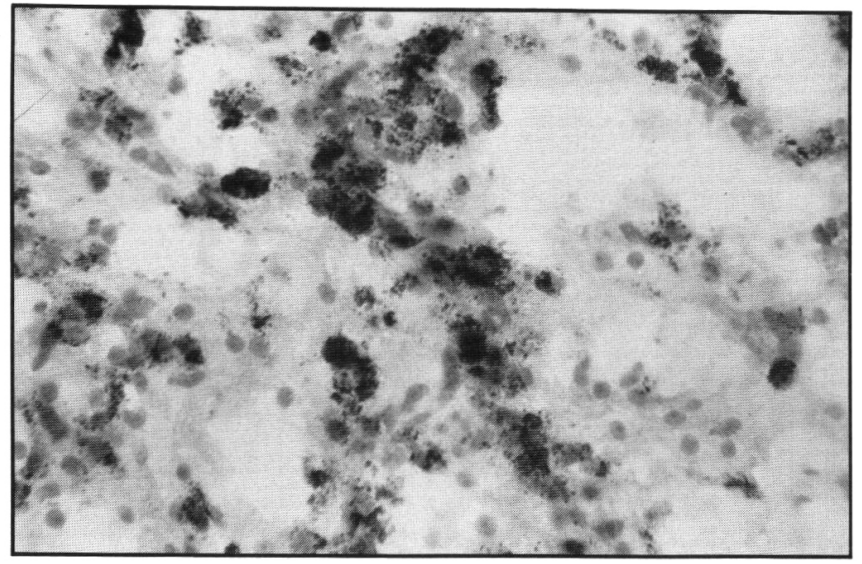

Figure 7

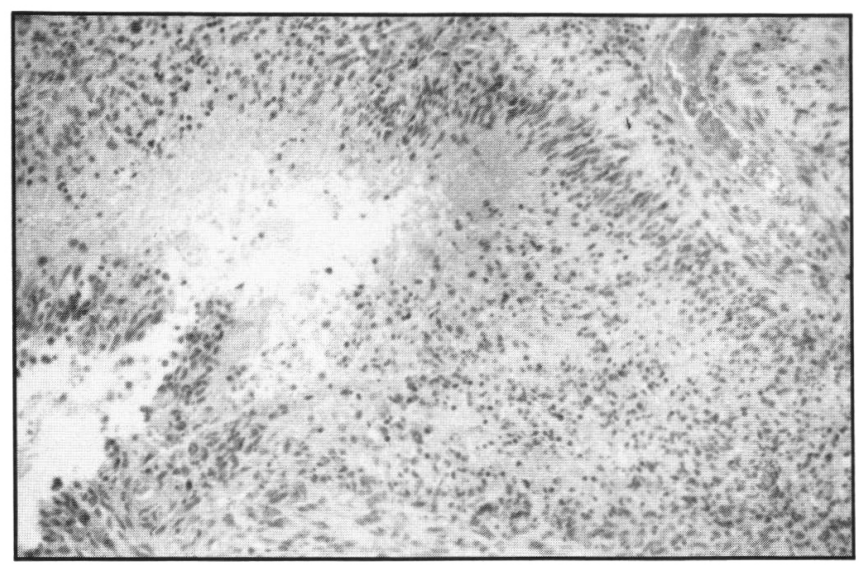

Figure 9

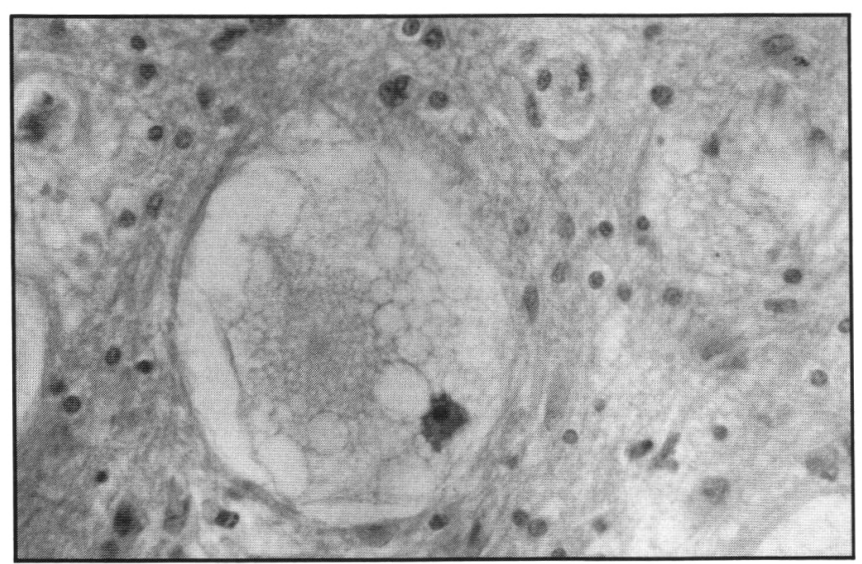

Figure 11

Figure 7 -Pleomorphic xanthoastrocytoma. Lipid droplets in neoplastic astrocytes. (frozen section, Oil-red-O fat stain, x 220)

Figure 9-Lipidized glioblastoma. Area of necrosis with pseudopalisading of surviving tumour cells. $(H \& E \times 90)$

Figure II - Higher power view of a large lipidized tumour cell. The cytoplasm is foamy, the nucleus and nucleolus show no signs of degeneration or early necrosis. ( $H \& E \times 260)$

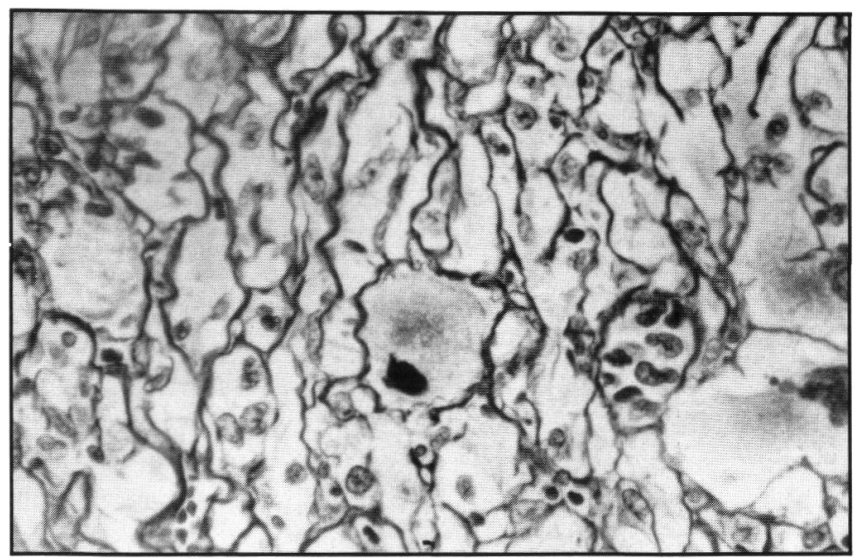

Figure 8

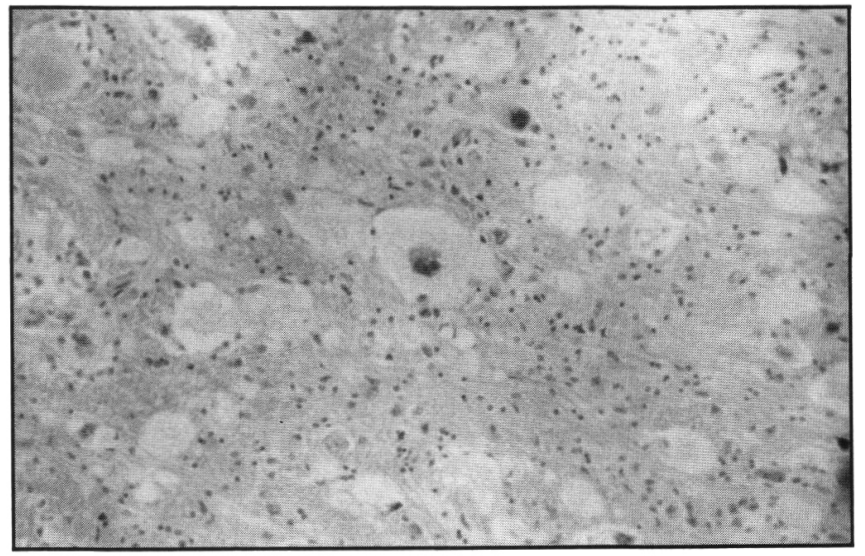

Figure 10

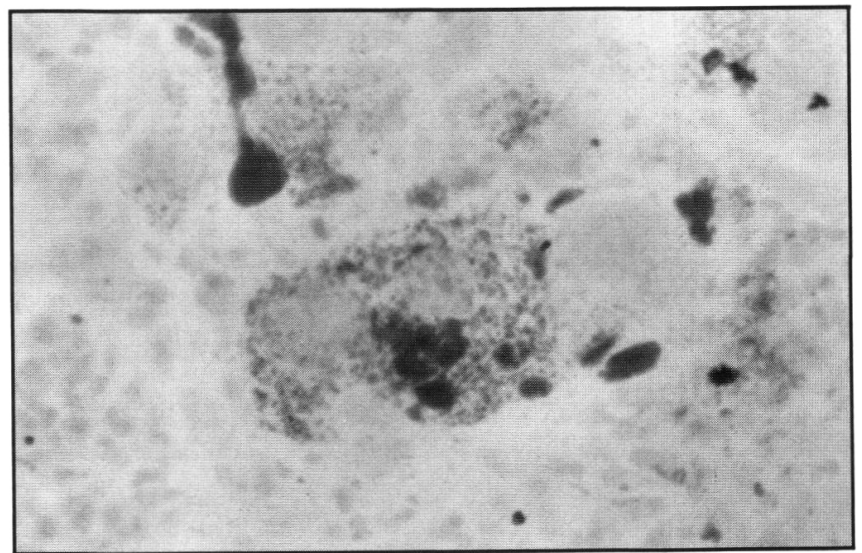

Figure 12

Figure 8-Same case as shown in Fig. 7. Individual lipidized tumour cells are surrounded by basement membranes. (Gomori's reticulin stain, $x 280$ )

Figure 10 - Same case as shown in Fig. 9. Individual lipidized neoplastic astrocytes infiltrate between fiber tracts of deep hemispheric white matter. $(H \& E \times 90)$

Figure 12 - Same tumour as shown in Figs. 10 and 11 . Frozen section with lipid droplets positively staining on fat stain. (Oil-red-O $\times 260)$ 
localized on the surface of the brain. As in the case of ordinary glioblastomas areas of necrosis with pseudopalisading are often found (Figure 9) but the hallmark of this entity is the presence of markedly lipidized neoplastic astrocytes infiltrating the brain (Figure 10). In these cells the lipidization does not appear to be a step towards necrobiosis, because by other criteria e.g. nuclear staining, nucleoli etc., these seem to be quite viable cells (Figure 11), but for reasons that at present are not well understood, they accumulate large amounts of lipid substances in their cytoplasm (Figure 12). Occasionally these cells too may be invested by reticulin fibers attesting to the fact that not only subpial astrocytes, but astrocytes in deeper locations may also at times elaborate basal laminae. By ordinary staining methods these tumours frequently imitate xanthosarcomas but the strong positivity of the GFAP stain in the cytoplasm of tumour cells helps to identify them as being malignant astrocytomas (Figure 13). Such "malignant gliomas with heavily lipidized foamy tumour cells" were first published in 1981 in the United States ${ }^{22}$ but since that time additional examples have been seen in other countries including Europe where a study of monstrocellular heavily lipidized malignant gliomas has been recently published by Gherardi et al from France.$^{23}$ Dr. Jans Muller called my attention to the fact that a case of "monstrocellular liposarcoma" published in Germany by Noetzel and Hauptmann ${ }^{24}$ was probably an early example of heavily lipidized glioblastoma but without GFAP staining it could not be identified as such. Indeed the importance and significance of the discovery of glial fibrillary acidic protein (GFAP) in the differential diagnosis between glial and connective tissue tumours cannot be overemphasized because in other respects the similarity between histiocytic neoplasms and astrocytomas can be quite bewildering. The "histiocytic" appearance of some xanthoastrocytomas has already been alluded to. It should also be stressed that true fibrous histiocytomas as primary central nervous system lesions or as the cerebral metastases from a distant primary source, may mimic astrocytic neoplasms very closely. Figure 14 illustrates a malignant fibrous histiocytoma of colonic origin: the tumour cells imitate gemistocytic astrocytes very closely; fortunately as a rule such cells are negative on the GFAP stain. A similar picture was provided by one of our cases of primary meningocerebral malignant fibrous histiocytoma (Figure 15). The tumour was just as lipidized and contained as many reticulin fibers as a pleomorphic xanthoastrocytoma, but could be well distinguished from a glial tumour by virtue of the total negativity of the tumour cells in the meninges as well as in those cells of the tumour that penetrated the brain following the VirchowRobin spaces around blood vessels. GFAP stain showed positively staining reactive astrocytes from the neighboring brain surrounding the tumour cell nests in a palisading fashion (Figure 16). Another source of difficulty in trying to differentiate astrocytic tumours from histiocytic ones, lies in the fact that certain characteristics of macrophages and histiocytes may be exhibited by cells of astrocytic lineage. One of the cytological markers that for awhile was considered to be characteristic of histiocytes, alpha-1-anti-trypsin or proteinase inhibitor has been found in a number of our pleomorphic xanthoastrocytomas (Figure 17) and was the source of some understandable confusion until other reports have confirmed the fact that this particular enzyme may be found in rather large numbers of gliomas of diverse histology including benign astrocytomas as well as glioblastomas. ${ }^{25}$ It is also noteworthy that $\mathrm{Tsao} \mathrm{et} \mathrm{al}^{26}$ observed some astrocytomas that showed a heavy histiocytic infiltrate, which possibly represented host reaction that might provide a better prognosis for the patient. Furthermore, large tumour cells occasionally contain engulfed lymphoctyes and plasma cells which may be variably considered as a sign of phagocytosis or conversely as active migration of small lymphoreticular cells into the cytoplasm of the large tumour cells (emperipolesis). This picture is most often observed when lymphocytes or plasma cells are seen within the cytoplasm of large histiocytes. However, we have observed the same phenomenon to occur in large neoplastic astrocytes (Figure 18) as was also described earlier by Müller and Dahmen. ${ }^{27}$

Thus, in terms of lipidization, formation of basal laminae, phagocytosis of other cells, and the presence of some cytoplasmic enzymes previously considered to be histiocytic, astrocytes in certain respects may imitate the behaviour of histiocytesmacrophages. Interestingly, Kusaka et al have shown just such transformation of cells of astrocyte lineage into macrophagelike cells in organotypic cultures of mouse spinal cord tissue. ${ }^{28}$

\section{Formation of cellular whorls in astrocytomas}

The formation of cellular whorls in brain tumours traditionally has been regarded as the hallmark of meningiomas, but this arrangement of tumour cells is by no means restricted to meningothelial elements. Abortive or poorly formed keratin pearls in primary and metastatic squamous carcinomas involving the brain or the meninges can imitate meningiomas quite closely and formations of small whorls have also been observed in medulloblastomas and in metastatic melanomas. ${ }^{29}$ Occasionally neoplastic astrocytes also arrange themselves in whorls; sometimes throughout the entire tumour, at other times only in a few foci of the neoplasm. ${ }^{29}$ One very striking example from a hemispheric astrocytoma of childhood was given to me by Dr. Taratuto from Buenos Aires, Argentina. You may observe that in some areas the tumour appears as a typical astrocytoma with multipolar star-shaped cells forming a network (Figure 19) whereas in other places the same tumour cells are seen wrapped around each other and forming whorls (Figure 20). Cells within the center and also in more peripheral portions of these whorls stain positively for GFAP, thereby attesting to their astrocytic origin (Figure 21).

\section{Myxoid and chondroid changes in astrocytomas}

The fact that neoplastic astrocytes may elaborate a loose mucoid substance has been known for a long time to observers of these neoplasms. Usually a slightly basophilic and metachromatic fluid appears between neoplastic cells gradually separating them and bringing about the formation of microcysts. In a fairly large number of tumours such microcysts coalesce to form grossly visible cysts. These cysts are known to be rather characteristic of low grade gliomas. Such myxoid transformation of the tumours usually remains at that stage but as we all know from general pathology, there is a close relationship between myxoid and chondroid changes, as witnessed in myxoid chondromas, chondromyxoid fibromas and myxoid chondrosarcomas. Accordingly, it should not be too surprising that in some of the glial tumours, the mucopolysaccharides produced by tumour cells may develop somewhat greater density and in the process begin to imitate, at least morphologically, the ground substance of chondroid tissue. As a result, islands of cartilage may on occasion appear in gliomas. It should be strongly empha- 


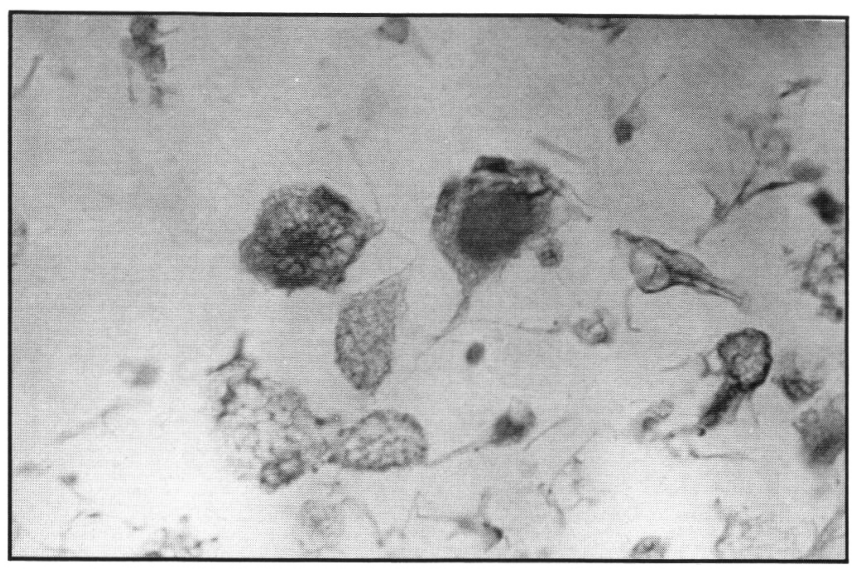

Figure 13

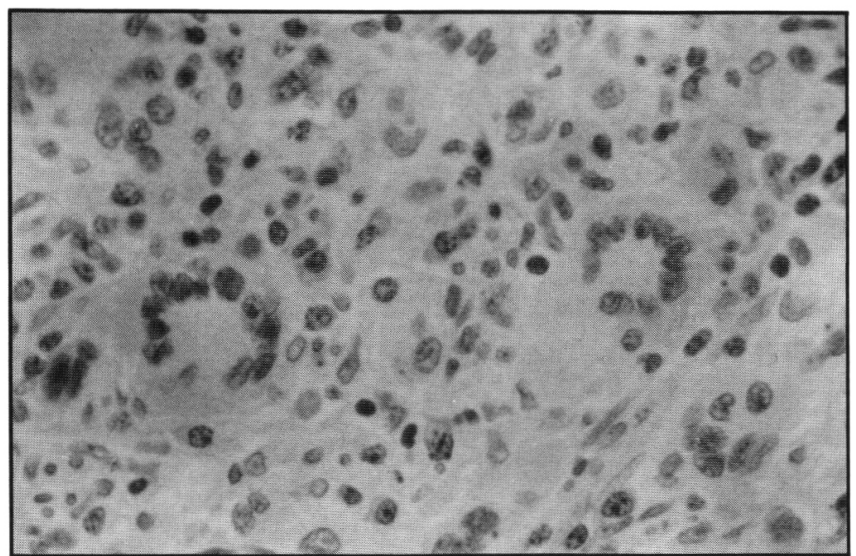

Figure 15

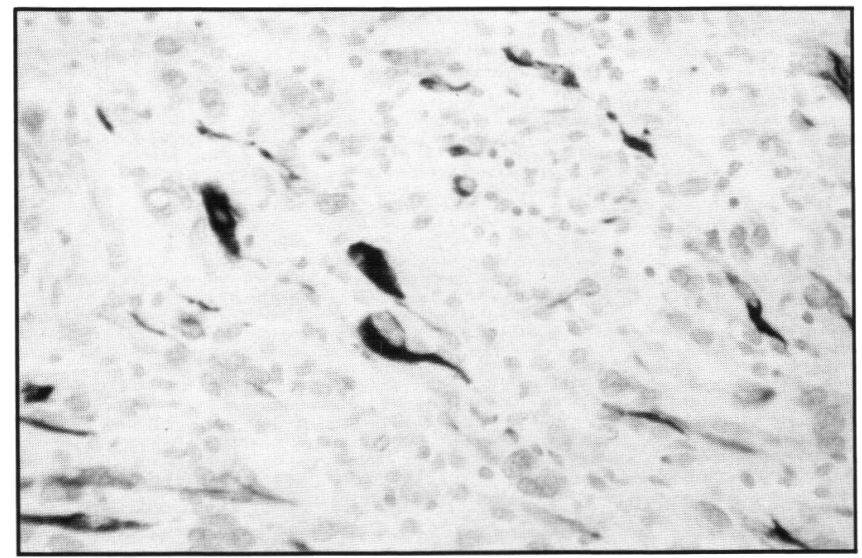

Figure 17

Figure 13 - Same case. In addition to being lipidized, the tumour cells contain glial fibrillary acidic protein. (Immunoperoxidase stain for GFAP $x$ 280)

Figure 15 - Primarymeningo-cerebralmalignantfibrous histiocytoma. Some of the mono- and multinucleated cells resemble astrocytes. $(H \& E \times 220)$

Figure 17 - Pleomorphic xanthoastrocytoma with many tumour cells staining positively for alpha-I-antitrypsin. (Immunoperoxidase stain for alphaI-antitrypsin $x 260$ )

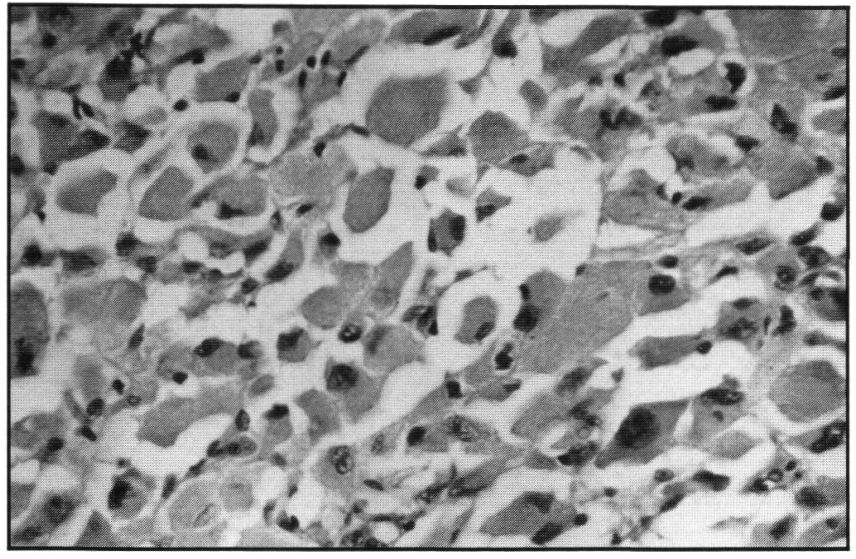

Figure 14

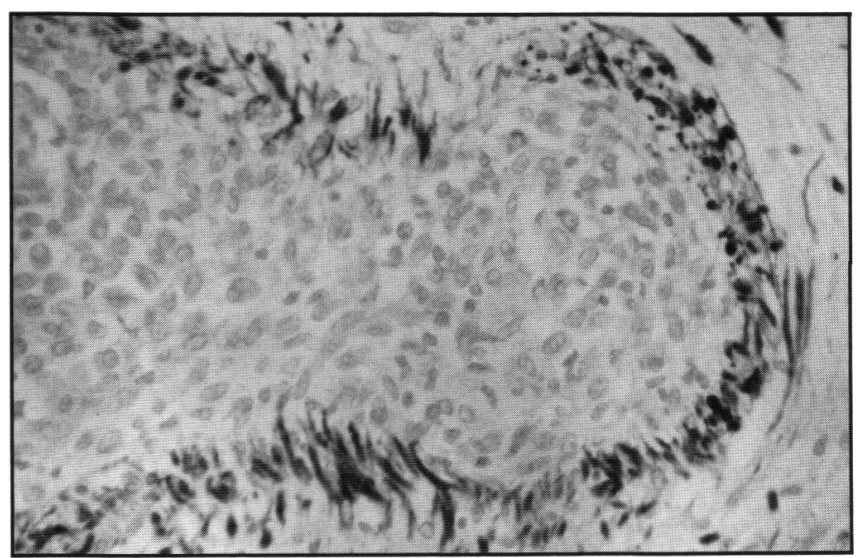

Figure 16

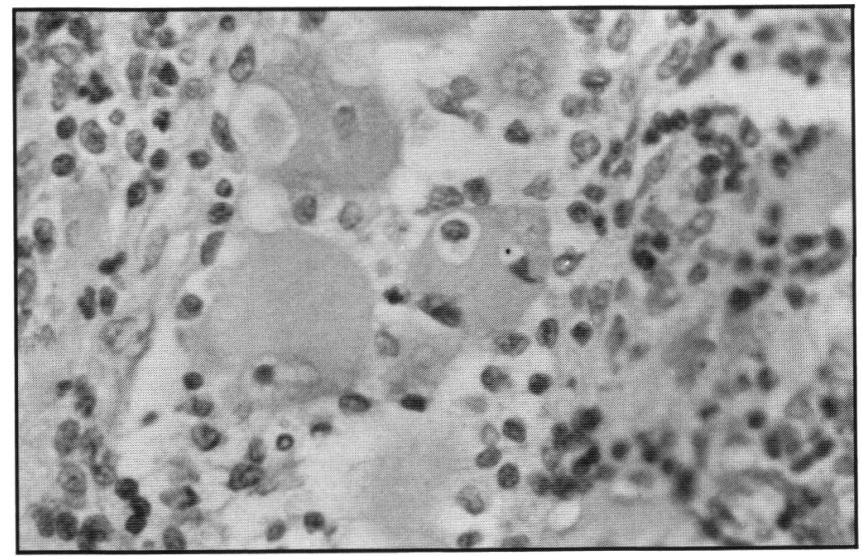

Figure 18

Figure 14 - Malignant fibrous histiocytoma of colon. metastatic to brain. The tumour cells resemble gemistocytic astrocytes. (H\&E $\times 160)$

Figure 16 - Same case as shown in Fig. 15. Nests of fibrous histiocytoma cells invade cortex and are "walled off" by reactive GFAP positive astrocytes. The tumour cells contain no GFAP. (Immunoperoxidase stain for GFAP $\times 200$ )

Figure 18 - Gemistocytic astrocytoma with lympho-histiocytic infiltrate. Some tumour cells contain engulfed lymphocyres (phagocytosis or emperipolesis). $(H \& E \times 220)$ 


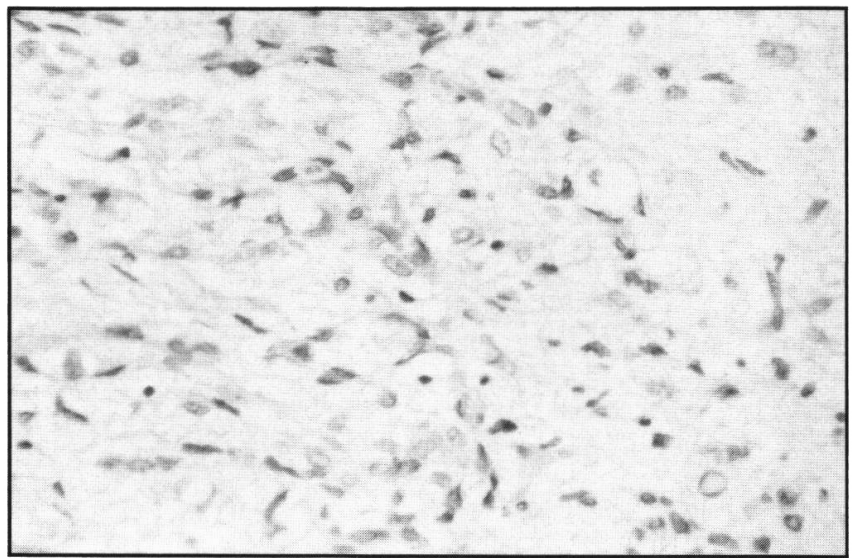

Figure 19

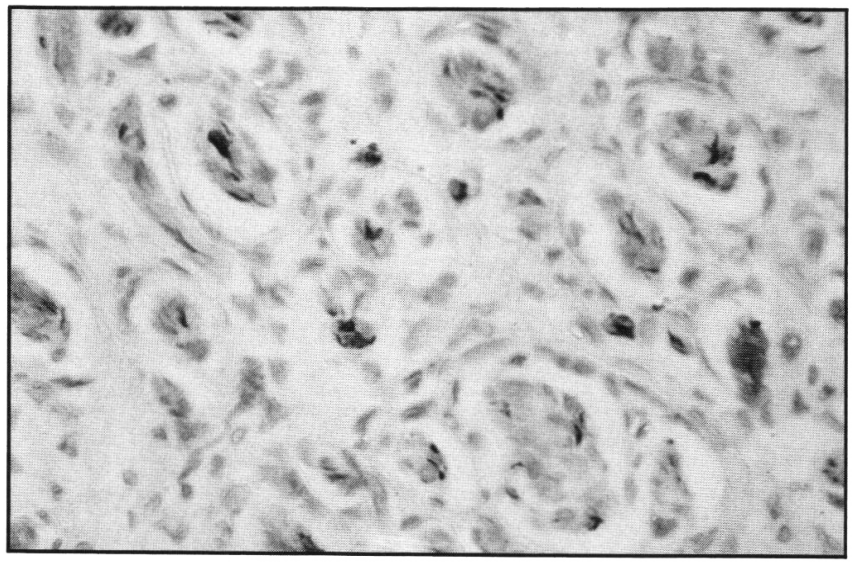

Figure 21

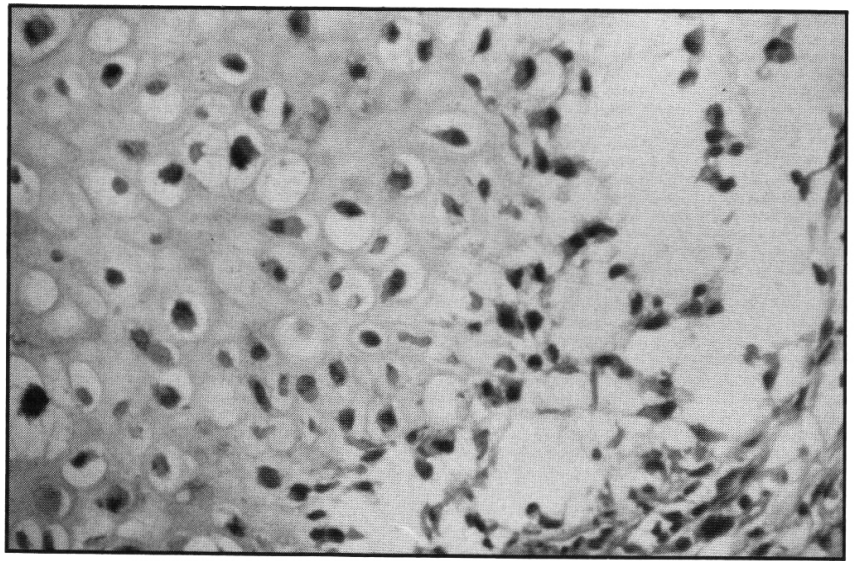

Figure 23

Figure 19 - From superficially located frontoparietal astrocytoma in a 14 year old boy. This area appears as an "ordinary" protoplasmic astrocytoma. $(H \& E \times 160)$

Figure 21 - Same case as in Figs. 19 and 20. Many tumour cells contain glial fibrillary acidic protein. (Immunoperoxidase stain for GFAP $x$ 140) (The case for Figs. 19-2I was submitted by Dr. A.L. Taratuto from Buenos Aires, Argentina.)

Figure 23 - Same case as shown in Fig. 22. In some areas of the tumour the mucoid ground substance became consolidated to suggest chondroid matrix. Neoplastic astrocytes are "trapped" within that matrix. $(H \& E x$ 260)

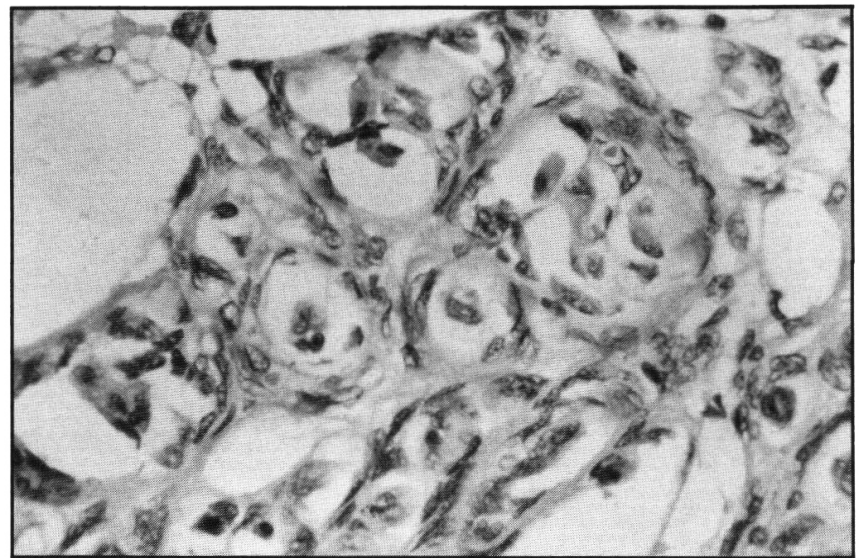

Figure 20

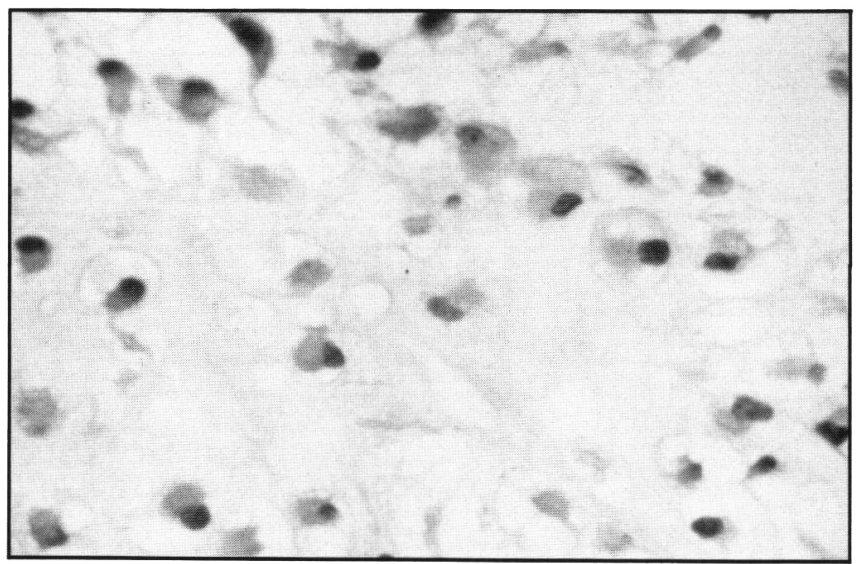

Figure 22

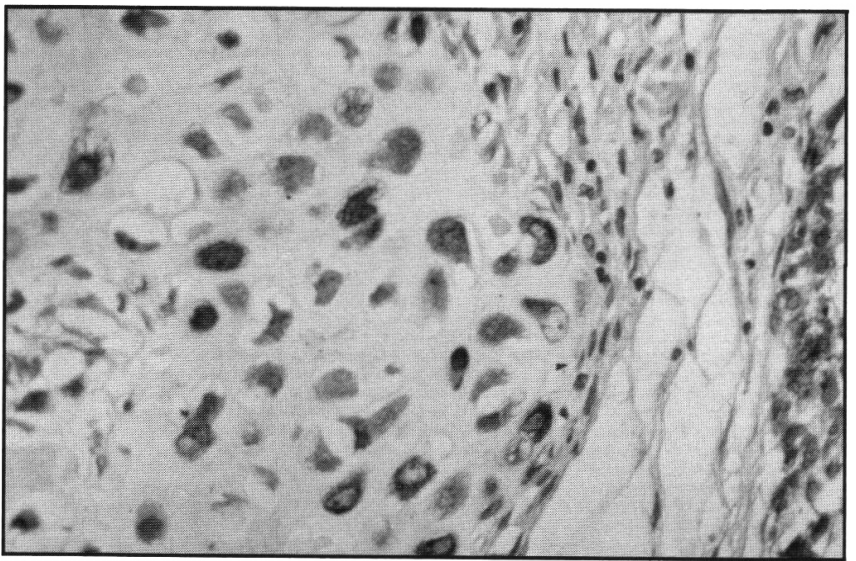

Figure 24

Figure 20-Same case as shown in Fig. 19. Marked whorling of tumour cells. $(H \& E x \quad 240)$

Figure 22 - Astrocytoma with mucoid ground substance and vacuoles in cytoplasm of tumour cells. $(H \& E \times 300)$

Figure 24 - Same case as in Figs. 22 and 23.Trapped astrocytes in chondroid ground substance stain strongly positive for GFAP. (Immunoperoxidase stain for GFAP $\times 260$ ) 
sized that cartilage has been found in a number of gliomas, particularly ependymomas, where chondroid tissue formed through metaplasia of the connective tissue stroma of the tumour and this has also been observed in papillomas of the choroid plexus. ${ }^{30,31}$ The phenomenon that we are referring to at this point, however, is the kind of transformation within the tumour where the cells involved are the neoplastic astrocytes themselves. The myxoid substance elaborated by them may become condensed to the point that it now simulates the ground substance of chondroid tissue, and astrocytes trapped in this substance begin to resemble chondrocytes as a result. ${ }^{32}$ In the process they also become vacuolated and accumulate more glycogen than tumour cells outside the chondroid foci (Figure 22) but in other respects they are still quite recognizable as astrocytes and they certainly retain strong positivity for GFAP staining (Figures 23,24). The process appears to be analogous to changes seen in pleomorphic adenomas of the salivary glands (formerly called "mixed tumours") where, as it is understood today, cells of epithelial lineage become surrounded by basophilic matrix material making the epithelial cells appear as chondrocytes. Such cartilage, as you well know, is histologically indistinguishable from the more "conventional" cartilage of mesenchymal origin.

\section{Epithelial Formations in Gliomas}

Drs. Manuelidis and Solitare in 1971 reported on their findings of human glioblastomas they grew in tissue culture as well as in guinea pig brains. ${ }^{33}$ They observed that the cultured cells initially retained their multipolar star-shaped appearance but in some of their cases the tumour cells became increasingly more closely packed and began to imitate clusters of epithelial cells. In one of their illustrations an astrocytoma grown in a guinea pig brain has come to imitate a carcinoma very closely. In our clinical material we had first observed this phenomenon in the glial portion of gliosarcomas where some neoplastic astrocytes. while identifiable by their positivity on the GFAP stain, have become so closely arranged that they imitated epithelial structures (Figure 25). In most instances a cribriform pattern predominated thus suggesting an adenoid type of carcinoma (Figures 26, 27). ${ }^{34}$ Obviously, it is very important for the patient's sake to differentiate between a primary brain tumour and a metastatic malignancy, since the mistaken diagnosis of a metastatic carcinoma obligates the clinicians to initiate a search for a primary lesion in order to be able to apply the most appropriate forms of radiation and/or chemotherapy. Such "search for a primary" may be very exacting in terms of discomfort and also financial cost, particularly for a patient who at that time is just recovering from a craniotomy. More recently, squamous differentiation of epithelial-like formations in glioblastoma as well as gliosarcomas has been observed by Dr. Rubinstein et al. ${ }^{35}$ These authors were able to demonstrate the simultaneous presence of glial fibrillary acidic protein as well as keratin in some of the epithelial-looking cell nests of glioblastomas (Figures 28, 29). In a recent publication Dr. Mandybur et al have again illustrated the transformation of glioma cells to epithelium-like masses in human gliomas, transplanted this time into nude mice. ${ }^{36}$ Actually it should not be too surprising that glial cells may assume the morphology of epithelial cells, since the entire central nervous system is derived from an invagination of the ectoderm and therefore it has in its ancestral lineage plenty of epithelial cells, including squamous cells of the epidermis. What should be surprising is that one does not encounter epithelial formations in central nervous system tumours more frequently. As it is, most epithelial formations encountered in neuroectodermal tumours are usually either columnar cell rows in medulloepitheliomas, ependymal canaliculi, or papillary formations of the choroid plexus rather than actual imitations of squamous epithelium of the epidermis.

\section{Astrocytic Tumours of the Brain with Aspects of Granular Cell Tumours}

The so-called granular cell tumours of the human body were first observed to occur in the tongue by Abrikosoff in $1926^{37}$ who considered them to be a form of myoblastoma originating from the lingual striated musculature. This notion held fast for many decades until more meticulous studies of such tumours showed them to be for the most part originating from Schwann cells of peripheral nerves ${ }^{38}$ Another form of granular cell tumours sometimes referred to as "choristoma" is usually encountered as a small incidental finding that only rarely reaches significant size ${ }^{39,40}$ in the posterior lobe or stalk of the pituitary gland. Occasional cases of granular cell tumours of the central nervous system have also been reported without exact identification of the cells of origin. ${ }^{41.42}$ Recently again through applying immunohistochemistry to identify GFAP in cells of such granular cell tumours some were shown to be of astrocytic origin. ${ }^{43,44}$ Two important articles about the subject have appeared in the May and July 1986 issues of the Journal of Neuropathology and Experimental Neurology by Dickson et a $\mathrm{l}^{45}$ and Kornfeld ${ }^{46}$ respectively. In these tumours the astrocytes become rounded with strikingly granular cytoplasm, the granules being diastase resistant positive on PAS stain (Figure 30). These typical "granular" cells also often contain large amounts of gliofibrillary acidic protein (Figure 31). Whether such tumours will follow a benign or more malignant course apparently depends on the other cellular characteristics such as mitotic activity, necrosis, etc. Kornfeld ${ }^{46}$ refers to the more malignant form of this tumour as a granular cell glioblastoma.

\section{Relative lymphocytes in gliomas vs. reactive astrocytes in lymphomas}

As pointed out in the first part of this paper, very small samples provided by stereotactically directed needle biopsies have greatly increased the risk of mistaken diagnoses in the realm of brain tumours. This is particularly true in those cases where more than one type of cell population is found in a given neoplasm. It has been known for some time that certain gliomas may contain a fairly heavy lymphocytic infiltrate, particularly in a perivascular arrangement. Takeuchi and Barnard ${ }^{47}$ have noted that such perivascular lymphocytic cuffing in gliomas is most often seen in the gemistocytic subtypes of astrocytomas. Our experience reflects the same observation. We have also found that some of these reactive lymphocytes may on occasion appear to be "activated", with large, hyperchromatic nuclei, and/or prominent nucleoli and thereby may imitate a fairly well differentiated lymphoma since it is well known that primary lymphomas of the brain preferentially develop within the adventitial spaces of cerebral blood vessels (Figures 32, 33). One of the histological hallmarks of cerebral lymphomas is the multiplication of basement membranes of those blood vessels that are involved by the lymphomatous process. It certainly contributes to diagnostic difficulties that in cases where reac- 


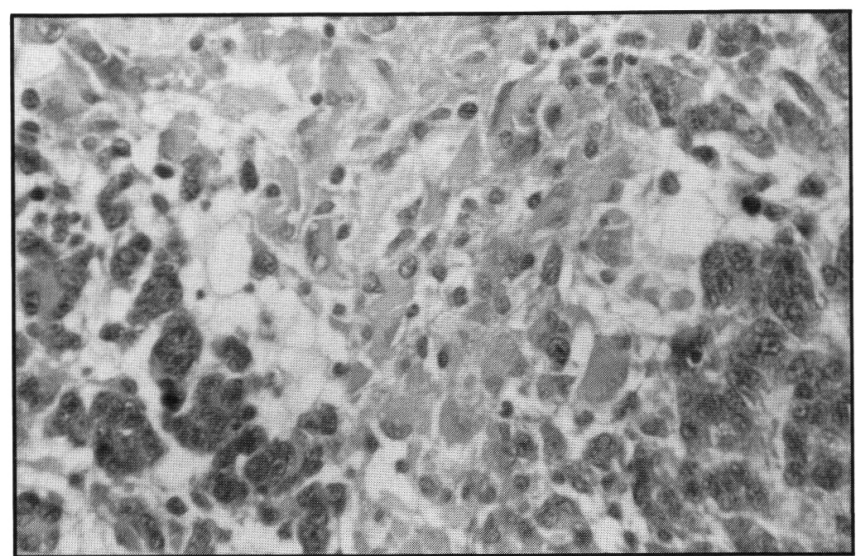

Figure 25

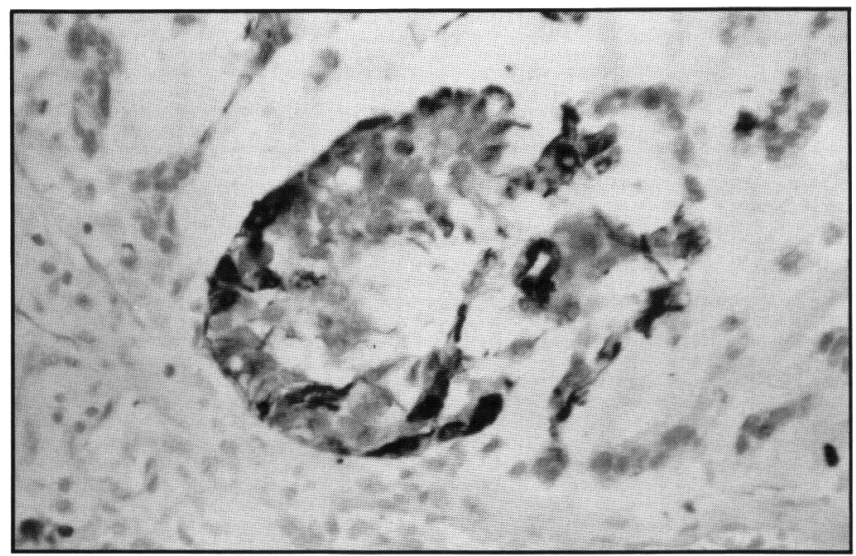

Figure 27

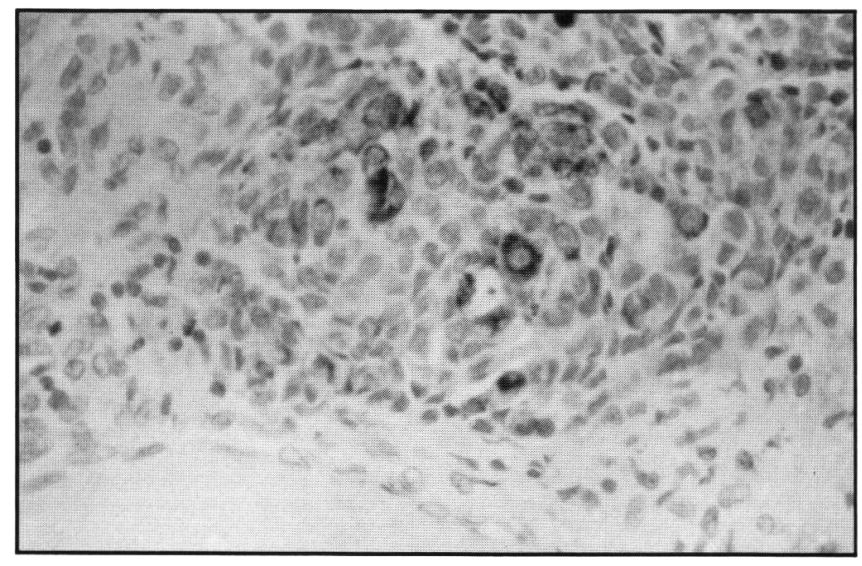

Figure 29

Figure 25 - Gliosarcoma with epithelioid areas in gliomatousportions. Transition from gemistocytic tumour cells (center) to more condensed darker epithelioid cells on left and right edges is seen. (H\&E $\times 280)$

Figure 27 - Same case as shown in Fig. 26. Several cells within the cribriform cell cluster contain GFAP. (Immunoperoxidase stain for GFAP, $x$ 220)

Figure 29 - Same case as shown in Fig. 28. Cells in squamoid area stain positively for keratin. (Immunoperoxidase stain for cytokeratin $x$ 180)

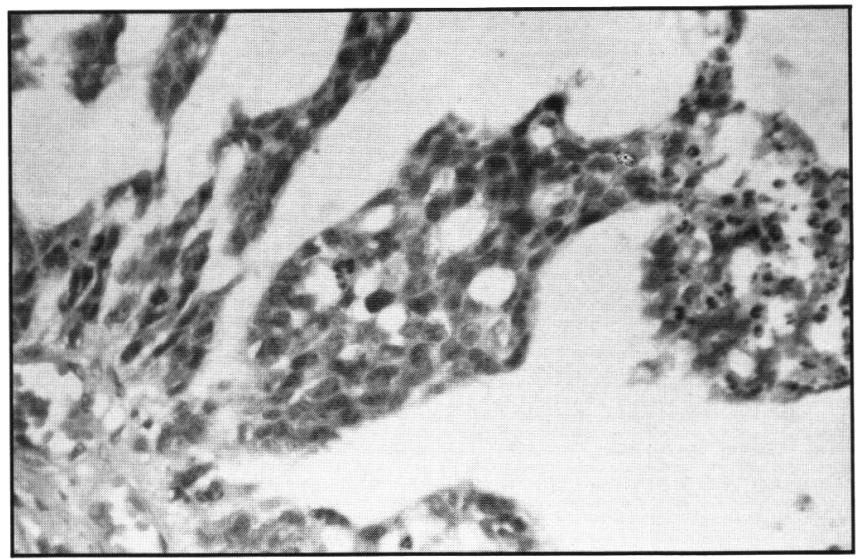

Figure 26

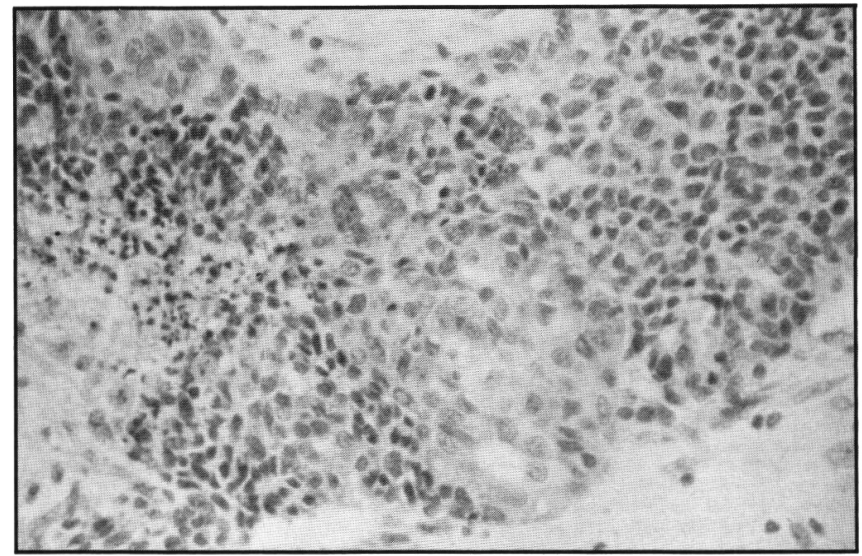

Figure 28

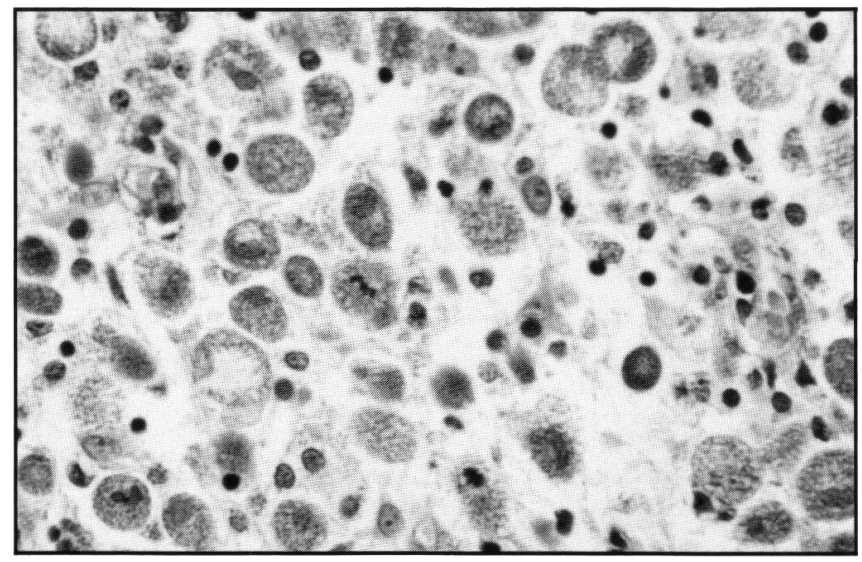

Figure 30

Figure 26 - In this area the tumour cells assume a cribiform pattern similar to that seen in adenocarcinomas. ( $H \& E \times 220)$

Figure 28 - Small cell glioblastoma with focus of squamous differentiation. $(H \& E \times 180)$

Figure 30 - Astrocytomapresenting as granular cell tumour of brain. Tumour cells have round contours and contain numerous PAS positive granules. (Periodic acid Schiff stain $\times 320$ ) 


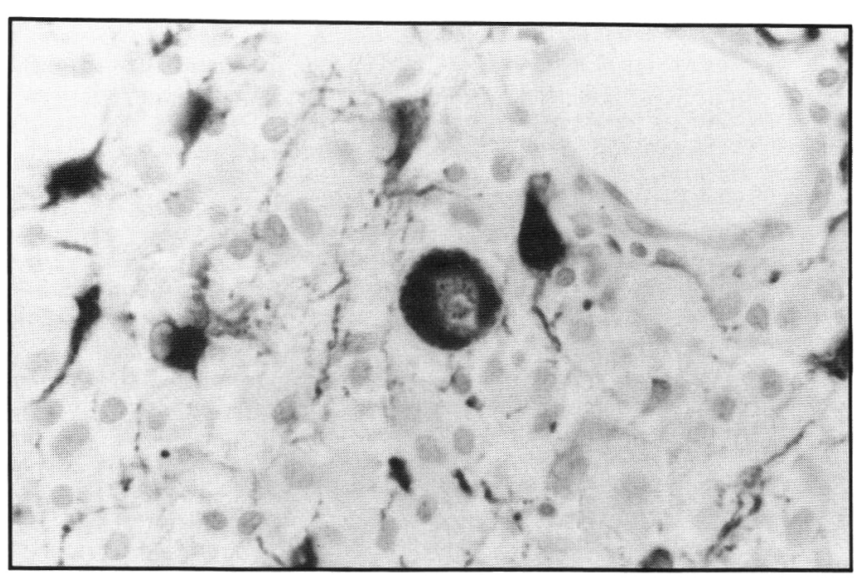

Figure 31

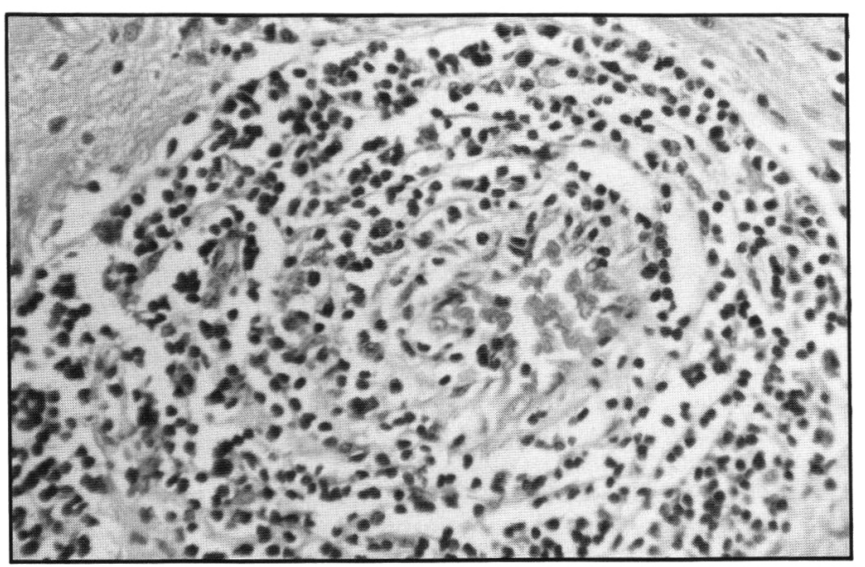

Figure 33

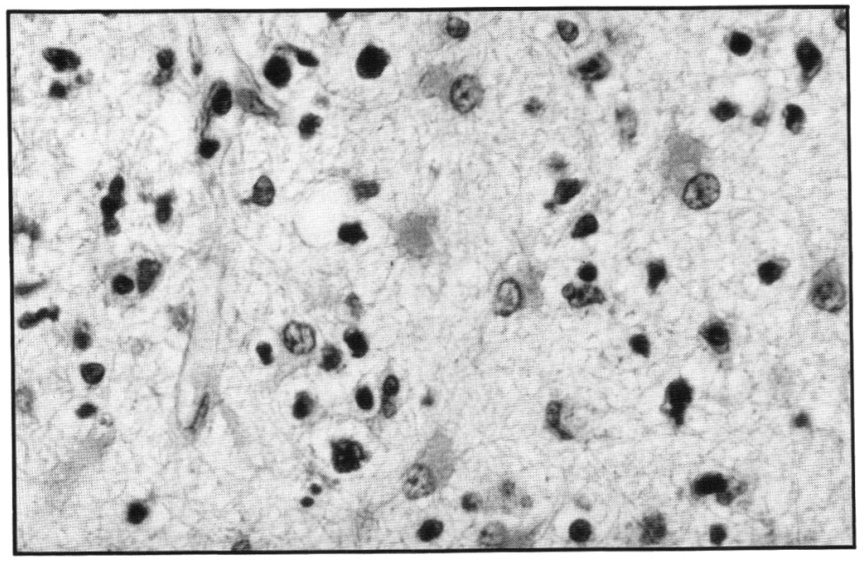

Figure 35

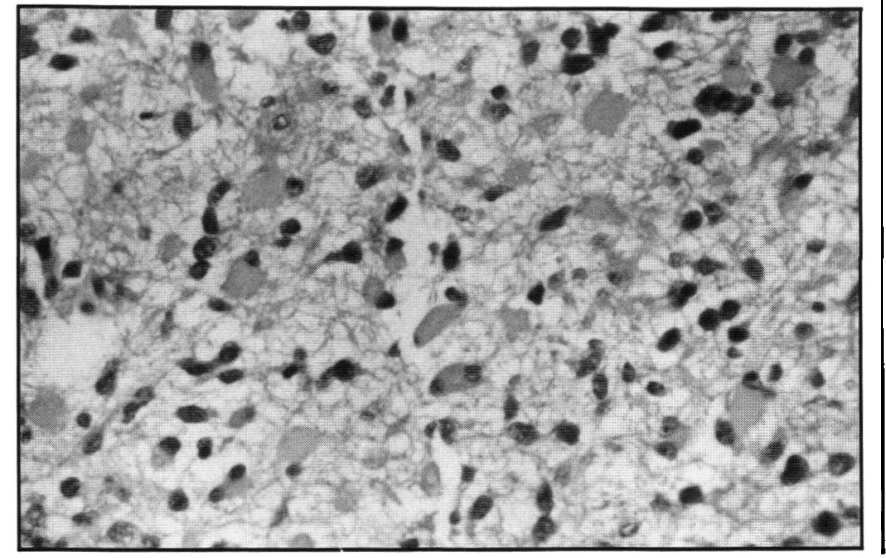

Figure 32

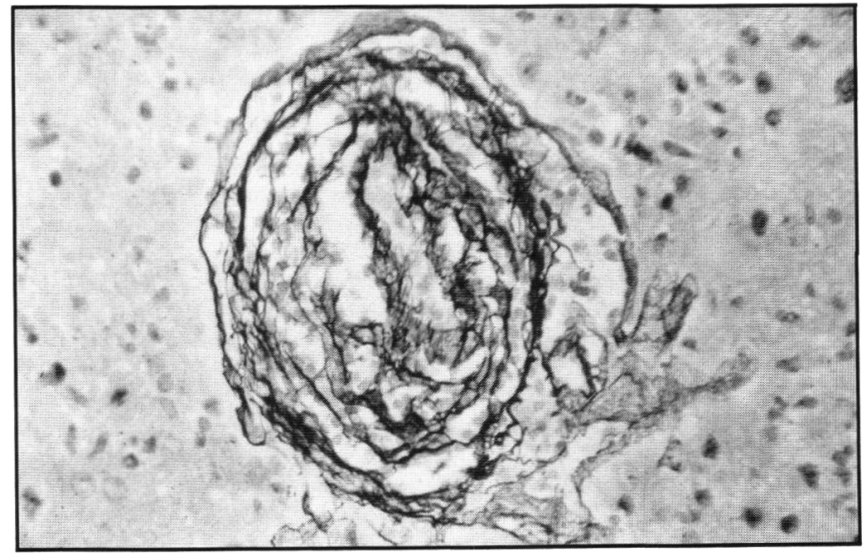

Figure 34

Figure 31 - Same case as shown in Fig. 30. Several granular numour cells, including the one in the center (with its nucleus undergoing mitosis) stain strongly for GFAP. (Immunoperoxidase stain for GFAP x 320)

Figure 32 - Predominantly gemistocytic astrocytoma from frontal lobe white matter in an adult. $(H \& E \times 180)$

Figure 33 - Same case as shown in Fig. 32. Marked perivascular lymphocytic cuffing. ( $H \& E \times 260)$

Figure 34 - Same case as shown in Figs. 32 and 33. Spliting and multiplication of basement membranes in adventitia of vessel with lymphocytic cuffing. This is a histologic feature commonly seen in cerebral lymphomas. (Gomori's reticulin stain $\times 260$ )

Figure 35 - A case of malignant lymphoma of the gastrointestinal tract. metastatic to brain. Mixed in with malignant lymphoreticular cells are reactive astrocytes which simulate better differentiated elements of an anaplastic astrocytoma. (H\&E x 360) (From case \#1), 1986 Diagnostic Slide Session of the CANP, submitted by Drs. MJ Strong. L-C Ang and JJ Gilbert). 
tive lymphocytes in a glioma involve the walls of the blood vessels, identical multiplication of basement membranes may take place (Figure 34).

Conversely, many cerebral lymphomas may have a striking presence of numerous astrocytes and on occasion such reactive astrocytes may show some pleomorphism of the nuclei which at first sight might suggest that we are dealing with a glioma (Figure 35). It is obvious that the smaller the sample we get for morphological analysis the greater the danger of mistaking one type of tumour for another. I think the only proper solution to this particular diagnostic problem again is to insist on larger or more pieces of tissue for histologic examination.

In summary, as I tried to illustrate in the foregoing, the chapter on astrocytomas is not a closed one. Continued observation and analysis of individual cases has enabled us in the past and will help us in the future to understand this group of tumours that are so variable in their morphologic appearance. I also hope that I was able to show in this lecture that the recognition of the different subgroups is of more than just theoretical importance as manifested by the relatively good prognosis of the pleomorphic xanthoastrocytomas in young individuals, the great clinical importance of differentiating astrocytomas with a whorling pattern from meningiomas, as well as metastatic carcinomas from astrocytic neoplasms that happen to imitate epithelial structures, and finally, by the obvious importance of the separation of astrocytomas with a lymphocytic reaction from their counterpart: primary lymphomas with marked reactive astrocytosis. It is certainly to be hoped that our continued activities and efforts in the discipline of Neuropathology will enable us in the future as it has in the past, to assist our patients who suffer from central nervous tissue tumours, and our clinical colleagues who are striving to alleviate such suffering.

\section{ACKNOWLEDGEMENT}

The author wishes to thank Mrs. Ella Olson for the typing of the manuscript.

\section{REFERENCES}

1. Olszewski J, Baxter D. Cytoarchitecture of the human brain stem. JB Lippincott Co, 1954.

2. Olszewski J. Subcortical arteriosclerotic endephalopathy. Review of the literature on the so-called Binswanger's disease and presentation of two cases. World Neurol 1962; 3: 359-375.

3. Berry K, Olszewski J. Central pontine myelinolysis. A case report. Neurology (Minneapolis) 1963; 13: 531-537.

4. Steele JC, Richardson JC, Olszewski J. Progressive supranuclear palsy. Arch Neurol 1964; 10: 333-359.

5. Zülch KJ. Brain tumours. Their biology and pathology. Translated by Olszewski J and Rothballer AB. Springer Publ Co New York, 1957.

6. Zülch KJ. Histological typing of tumours of the central nervous system. World Health Organization, Geneva, 1979; 19-20.

7. Kepes JJ, Rubinstein LJ, Eng LF. Meningocerebral xathoastrocytoma. A distinctive glioma of young subjects, presumably originating from subpial astrocytes, with relatively favorable prognosis. Abstract. VIIIth International Congress of Neuropathology, Washington D.C., 1978; p. 641.

8. Kepes JJ, Rubinstein LJ, Eng LF. Pleomorphic xanthoastrocytoma: A distinctive meningocerebral glioma in young subjects with relatively favorable prognosis: A study of 12 cases. Cancer 1979; 44: 1839-1852.

9. Kepes JJ, Kepes M, Slowik F. Fibrous xanthomas and xanthosarcomas of the meninges and the brain. Acta Neuropathol (Berl) 1973; 23: 187-199.
10. Ramsey H. Fine structure of the surface of the cerebral cortex of human brain. J Cell Biol 1965; 26: 323-333.

11. Kusaka H, Hirano A, Bornstein MB, et al. Basal lamina formation by astrocytes in organotypic cultures of mouse spinal cord tissue. J Neuropathol Exp Neurol 1985; 44: 295-303.

12. Kuhajda FP, Mendelsohn G, Taxy JB, Long DM. Pleomorphic xanthoastrocytoma: Report of a case with light and electron microscopy. Ultrastruct Pathol 1981; 2: 25-32.

13. Weldon-Linne C, Victor TA, Groothius DR, et al. Pleomorphic xanthoastrocytoma: Ultrastructural and immunohistochemical study of a case with a rapidly fatal outcome after surgery. Cancer 1983; 52: 2055-2063.

14. Heyerdahl Strøm E, Skullerud K. Pleomorphic xanthoastrocytoma: report of 5 cases. Clin Neuropathol 1983; 2: 188-191.

15. Maleki M, Robitaille Y, Bertrand G. Atypical xanthoastrocytoma presenting as a meningioma. Surg Neurol 1983; 20: 235-238.

16. Sakai H, Okada K, Yada K, et al. Pleomorphic xanthoastrocytoma (Kepes). Neurol Surg (Japan) 198I; 13: 1519-1524.

17. Jones MC, Drut R, Raglia G. Pleomorphic xanthoastrocytoma: a report of two cases. Pediatr Pathol 1983; 1: 459-467.

18. Gomez JG, Garcia JH, Colon LE. A variant of cerebral glioma called pleomorphic xanthoastrocytoma: case report. Neurosurgery 1985; 16: 703-706.

19. Grant JW, Gallagher PJ. Pleomorphic xanthoastrocytoma. Immunohistochemical methods for differentiation from fibrous histiocytomas with similar morphology. Am J Surg Pathol 1986; 10: 336-341.

20. Allegranza A, Migliavacca F, Mariani C. Xantoastrocitoma pleomorfo cerebromeningeo. Istocitopatologia 1980; $2: 137-141$.

21. Palma L, Maleci A, Di Lorenzo N, et al. Pleomorphic xanthoastrocytoma with 18 year survival. Case report. J Neurosurg 1985;63: 808-810.

22. Kepes JJ, Rubinstein LJ. Malignant gliomas with heavily lipidied (foamy) tumour cells: A report of three cases with immunoperoxidase study. Cancer 1981; 47: 2451-2459.

23. Gherardi R, Baudrimont M, Nguyen JP, et al. Monstrocellular heavily lipidized malignant glioma. Acta Neuropathol (Berl) 1986; 69: 28-32.

24. Noetzel H, Hauptmann A. Zur Frage der Identität des sogenannten monstrocellulären Hirnsarkoms und des Liposarkoms. Frankf Zeitschr f Pathol 1964; 73: 535-539.

25. Zuccarello M, Sawaya R, Ray MB. Demonstration of alpha1-proteinase inhibitor in brain tumours. J Neuropathol Exp Neurol 1986; $45: 321$

26. Tsao M-S, Becker L, Finlayson M. Giant cell astrocytoma with histiocytic infiltrate. Acta Neuropathol (Berl) 1983; 59: 75-77.

27. Müller W, Dahmen HG. Lymphocytes within glial cells ("emperipolesis") in a case of a granular cell tumour. Acta Neuropathol (Berl) 1978 ; 44; 163-165.

28. Kusaka H, Hirano A, Bornstein MB. Transformation of cells of astrocyte lineage into macrophage-like cells in organotypic cultures of mouse spinal cord tissue. J Neurol Sci 1986; 72: 77-89.

29. Kepes JJ. Cellular whorls in brain tumours other than meningiomas. Cancer 1976; 37: 2232-2237.

30. Mathew T, Moossy J. Gliomas containing bone and cartilage. J Neuropathol Exp Neurol 1974; 33: 456-471.

31. Siqueira EB, Bucy PC. Case report: Chondroma arising within a mixed glioma. J Neuropathol Exp Neurol 1966; 25: 667-673.

32. Kepes JJ, Rubinstein LJ, Chang $\mathrm{H}$. The role of astrocytes in the formation of cartilage in gliomas. Am J Pathol 1984;117:471-483.

33. Manuelidis EE, Solitare GB. Glioblastoma multiforme. In: Pathology of the Nervous System Vol II. Chapter 154, Minckler J, ed. McGraw-Hill New York. 1971; 2063-2066.

34. Kepes JJ, Fulling KH, Garcia JH. The clinical significance of "adenoid" formations of neoplastic astrocytes imitating metastatic carcinomas, in gliosarcomas. Clin Neuropathol 1982; 1 : 139-150.

35. Rubinstein LJ, Mørk SJ, Kepes JJ, et al. Squamous differentiation of epithelial-like formations in glioblastoma and gliosarcoma. $\mathbf{J}$ Neuropathol Exp Neurol 1986; 45: 327

36. Mandybur TI, Sawaya R, Ormsby 1 . The morphology and biologic behavior of human glioblastoma growing in nude mice. Cancer 1986; 58: 1061-1069.

37. Abrikosoff A. Über Myome ausgehend von quergestreifter willkürlicher Muskulatur. Virch Arch Pathol Anat 1926; 260: 215-233. 
38. Chimelli L, Symon L, Scaravilli F. Granular cell tumour of the fifth cranial nerve: Further evidence for Schwann cell origin. J Neuropathol Exp Neurol 1984; 43: 634-642.

39. Vaquero J, Leunda G, Cabezudo JM, et al. Granular pituicytomas of the pituitary stalk. Acta Neurochir 1981; 59: 209-215.

40. Becker DH, Wilson CB. Symptomatic parasellar granular cell tumours. Neurosurgery 1981; 8: 173-180.

41. Markesbery WR, Duffy-PE, Cowen D. Granular cell tumours of the central nervous system. J Neuropathol Exp Neurol 1973; 32: $92-109$.

42. Ule G, Tschahargane G, Haag D, et al. Maligner Granularzelltumor des Grosshirnmarkes. Morphologische, cytophotometrische und neurochemische Befunde. Acta Neuropathol (Berl) 1975; 32: 143-155.

43. Pasquier $B$, Pasquier $D$, Gasnier $F$, et al. Tumeurà cellules granuleuses intracerebrale primitive: Arguments en faveur de son origine astrocytaire. Une observation antatomoclinique avec revue de la literature. Arch Anat Cytol Path 1981; 29: 215-220.

44. Lechevalier B, Mandard JC, Adam Y, et al. Tumeur à cellules granuleuses d'un hemisphere cerebral: Interet de la recherche de la proteine acide gliofibrillaire. Rev Neurol 1982; 138:619-629.

45. Dickson DW, Suzuki KI, Kanner R, et al. Cerebral granular cell tumour: Immunohistochemical and electron microscopic study. J Neuropathol Exp Neurol 1986; 45: 304-314.

46. Kornfeld M. Granular cell glioblastoma: A malignant granular cell neoplasm of astrocytic origin. J Neuropathol Exp Neurol 1986; 45: 447-462.

47. Takeuchi J, Barnard RO. Perivascular lymphocytic cuffing in astrocytomas. Acta Neuropathol (Berl) 1976; 35: 265-271. 